\title{
Local Heroes
}





\title{
Local Heroes
}

\author{
THE POLITICAL ECONOMYOF \\ RUSSIAN REGIONAL GOVERNANCE
}

*

KATHRYN STONER-WEISS

PRINCETON UNIVERSITY PRESS

PRINCETON AND OXFORD 
Copyright $(\mathcal{C} 1997$ by Princeton University Press

Published by Princeton University Press, 41 William Street,

Princeton, New Jersey 08540

In the United Kingdom: Princeton University Press,

3 Market Place, Woodstock, Oxfordshire OX20 1SY

All Rights Reserved

Second printing, and first paperback printing, 2002

Paperback ISBN 0-691-09281-8

The Library of Congress has cataloged the cloth edition of this book as follows

Stoner-Weiss, Kathryn, 1965-

Local heroes : the political economy of Russian regional

governance / Kathryn Stoner-Weiss.

p. $\mathrm{cm}$.

Includes bibliographical references and index.

ISBN 0-691-01195-8 (cl : alk. paper)

1. Local government-Russia (Federation) 2. Representative government and representation-Russia (Federation) 3. Regional planning-Russia (Federation) 4. Russia (Federation)-Economic policy-1991- I. Title.

JS6117.3.A3S76 1997

351.47-dc21 97-7355

British Library Cataloging-in-Publication Data is available

This book has been composed in Sabon

Printed on acid-free paper. $\infty$

www.pupress.princeton.edu

Printed in the United States of America

$\begin{array}{lllllllll}3 & 5 & 7 & 9 & 10 & 8 & 6 & 4 & 2\end{array}$ 
To Eric 
